\title{
HATÁRON ÁTNYÚLÓ KULTÚRAGAZDASÁG INTEGRÁLT FEJLESZTÉSE A MAGYAR-SZLOVÁK HATÁRON
}

\author{
OCSKAY GYULA - HARDI TAMÁS \\ INTEGRATED DEVELOPMENT OF CULTURAL ECONOMY \\ AT THE HUNGARIAN-SLOVAK BORDER
}

\begin{abstract}
Based on the experiences of a specific project development work, this study seeks to answer why there have not been many successful projects targeting the valorization of cultural heritage at the Hungarian-Slovak border which have resulted in a stronger cohesion of the borderland. It also examines how similar initiatives in the future could contribute to this aim. For this purpose, the authors first provide an overview of the major issue-relevant conclusions of border studies literature, with special emphasis on the topic of subjective (especially cultural) distance. Subsequently, they examine the values and mistakes of the INTERREG programmes supporting cross-border cooperation, highlighting the necessity of integrated developments. In the third part of the study, based on the experiences gained from the INTERREG EUROPE project called WAVE targeting the valorization of water-based cultural heritage and implemented with the participation of the Ister-Granum EGTC, as well as the territorial action plans applied by the Slovakia-Hungary INTERREG V-A programme, they make a proposal on the cross-border integrated development of cultural economy.
\end{abstract}

Keywords: cultural economy, cross-border cooperation, Ister-Granum EGTC, INTERREG

\section{Bevezetés}

Az alábbi tanulmány egy konkrét projektfejlesztő munka tapasztalatait felhasználva arra keresi a választ, hogy a magyar-szlovák határon a kulturális örökség valorizációját célul kitűző rengeteg sikeres pályázat miért nem eredményezte a határtérség erősebb kohézióját, és hogy miként lehetne ezen az eredménytelenségen javítani. Az érintett határszakasz 1999 óta vesz részt folyamatosan az Unió támogatásával múködő határ menti együttmúködési programokban (a továbbiakban a tanulmányban a programok egyszerúsített elnevezését fogjuk használni a könnyebb áttekinthetőség érdekében). A kulturális örökség témája fokozatosan vált egyre jelentősebbé a magyar-szlovák programok történetében, és ma már a projektek több mint 1/3-át érinti, miközben a természeti és kulturális örökség védelme és valorizációja a teljes programköltségvetésnek mintegy 2/3-át fedi le (1.táblázat).

A fenti programok jóvoltából épült meg a Kelemantia Múzeum Izsán (Iža), újult meg a sárospataki bazilika és a kassai Szent Erzsébet dóm, a mándoki Forgách és a galántai Esterházy kastély, a királyhelmeci (Královský Chlmec) Mailáth József Regionális Múzeum, az alsósztregovai és a csesztvei Madách múzeumok; továbbá számos kulturális rendezvény, hagyományokat feldolgozó kezdeményezés valósult meg az uniós támogatásoknak köszönhetően.

Ha azonban a statisztikai adatok mögé tekintünk, nem látjuk a határtérség kulturális integrációjának nyomait, nem tudjuk bejárni a létrehozott kulturális turisztikai témautakat, és egy-két kivételtől eltekintve nehéz felfedezni a korábban a program támogatásával felújított kulturális örökségi elemek menedzsmentjei közötti együttmúködést.

A jelen tanulmányban egyrészt ennek a jelenségnek próbáljuk egyfajta magyarázatát adni „határtani” szempontból és az INTERREG programok tapasztalatai alapján; másrészt 
A magyar-szlovák határon átnyúló programok keretében megvalósított

kulturális témájú projektek száma és aránya (1995-2020),

a VÁTI (2002), LADOS M. (2006), ÁSZ (2008), EC (2016b) alapján

Number and share of cultural theme projects implemented

within the frameworks of Hungarian-Slovak cross-border programmes (1995-2020),

by VÁTI (2002), LADOS, M. (2006), ÁSZ (2008), EC (2016b)

\begin{tabular}{|c|c|c|c|c|}
\hline & $\begin{array}{l}\text { Phare CBC } \\
(1995-1996, \\
1999-2003)\end{array}$ & $\begin{array}{l}\text { INTERREG } \\
\text { III HUSKUA } \\
\text { (2004-2006) }\end{array}$ & $\begin{array}{l}\text { HUSK ETE } \\
\text { CBC } \\
(\mathbf{2 0 0 7 - 2 0 1 3})\end{array}$ & $\begin{array}{c}\text { SKHU } \\
\text { INTERREG } \\
\text { V-A } \\
\text { (2014-2020) } \\
\text { (2020. áprilisig) }\end{array}$ \\
\hline $\begin{array}{l}\text { Összes megvalósított } \\
\text { vagy megkezdett } \\
\text { projekt száma }\end{array}$ & 111 & 82 & 243 & 143 \\
\hline $\begin{array}{l}\text { Ebbő́l kulturális tema- } \\
\text { tikájú projektek száma }\end{array}$ & 10 & 19 & 48 & 52 \\
\hline $\begin{array}{l}\text { A kulturális projektek } \\
\text { részaránya }(\%)\end{array}$ & 9,00 & 23,17 & 19,75 & 36,36 \\
\hline $\begin{array}{l}\text { A program egészére } \\
\text { allokált ERFA- } \\
\text { támogatás összege } \\
\text { (millió euró) }\end{array}$ & 11,76 & 16,39 & 165,10 & $* 155,80$ \\
\hline
\end{tabular}

* tervezett

az Ister-Granum Európai Területi Társulás (ETT) részvételével, az INTERREG EUROPE program támogatásával megvalósítás alatt álló kulturálisörökség-menedzsment témájú projekt példáján keresztül a lehetséges megoldásra is javaslatot teszünk.

A tanulmányban a helyi (természeti, kulturális és szellemi) örökség értékőrző hasznosítását értjük (a pénzügytudományokból kölcsönzött) valorizáció alatt. Maga a terminus pontosan nem fordítható le magyarra, a legközelebb az örökségmenedzsment áll hozzá. Ugyanakkor a valorizáció egyszerre feltételezi az értékőrzést (annak identitást konstituáló tényezőivel együtt), az értékvesztés kompenzációját, valamint az e célból mozgásba hozott kreativitást, illetve magát az értékesítést is. (RAKITOVAC, K. A.-URošEvić, N. 2017; Cerderias A. et al. 2018)

\section{A kulturális kapcsolatok szerepe a határok légiesítésében}

A határ mindig a távolságot helyezi a földrajzi térbe (Lösch, A. 1954; NiJkAMP, P. et al. 1990). A természeti határok (hegyvonulatok, széles folyamok, tengerszorosok) megnehezítik, lelassítják a két pont közötti eljutást, megnövelik az utazási időt. Az adminisztratívpolitikai határok az eltérő szabályrendszerek, eljárások, fizetőeszközök, nyelv stb. révén teszik nehézkessé ügyeink intézését, céljaink elérését. Ezek az objektív akadályok jelentôs szerepet játszanak a szubjektív távolságérzet kialakulásában. A közlekedés fejlődése révén a fizikai távolságokat egyre könnyebben legyőzhetjük: átrepülhetünk a legmagasabb hegység és a legszélesebb óceán fölött, alagutakon keresztül már vonattal vagy autóval is átjuthatunk Európa legmagasabb hegycsúcsai és akár tengerszorosai alatt is. Az európai 
integráció folyamata arra is számos példával szolgál, miként lehet csökkenteni az adminisztratív határok elválasztó hatását az egységes piacot és a „szabadság négy pillérét” (a személyek, az áruk, a tôke és a szolgáltatások szabad áramlását) érintő szabályozási háttérnek vagy éppen a többszintû kormányzás feltételrendszerének a megteremtésével.

Ugyanakkor a korlátok szubjektív érzékelésében nagyon nehéz változásokat elérni. A kiindulási pontot ebból a szempontból az a tapasztalatunk jelenti, hogy a határ túloldalán fekvő települést mindig távolabbinak érezzük, érzékeljük, mint a határon innenit (VAN HouTUM, H. 1999; Hardi T. et al. 2009; Medve-BÁlint G. 2013). Ezt nevezi van Houtum, H. (2000) kognitív távolságnak, a valóság kognitív leképeződésének, ami a tapasztalatainkból és a megszerzett tudásunkból építkezik. A mentális távolság a határ két oldalán fekvő térségek és az ott érvényes konvenciók közötti különbségek megsaccolását (estimation of the differences) jelenti (VAn Houtum, H. 2000). Ahogy HARdi T. et al. (2009) fogalmaz: „A mentális határ fogalma alatt azt a képzeletbeli vonalat értjük, amely az egyes ember területi identitásának végső földrajzi pontjait köti össze, s amelyen belül élőket még a 'mi' csoportjába, s a rajta kívül élőket az 'ők' csoportjába sorolja, tehát egy pszichikai távolság térbeli leképezése" (p. 20). Ez a közösségtudat fontos ragasztóanyaga a társadalmi szövetnek, ez biztosítja az otthonosságot (familiarity), biztonságérzetet (security) és a közös identitást (identity) a meghatározott területen élők számára (VAN HouTum, H. 1999).

Míg a mentális határvonal teljesen racionális alapú, az érzelmi távolság (affective distance) már elóítéleteket és sztereotípiákat is tartalmaz, éppen a területi alapú identitást előidézó élettapasztalatokra, a mentális határ képzetére és az ehhez társított elképzelésekre alapozva (vAn Houtum, H. 2000). Az érzelmi távolság rajzolja meg az egyén körül azt az affektív teret (affective space), amelyben világosan elkülönül itt - ott, mi - ôk, miénk - övék, és ez kifejezésre jut az illető individuumok viselkedésében (action space) is (VAN Houtum, H. 1999). Más szóval a szubjektív határ képzete alakítja ki az emberben a szomszédos térség más-ságát (otherness), idegenségét (VAN HouTum, H. et al. 2005; RAJARAM, P. K.-Grundy-Warr, C. 2007; Agnew, J. 2008; ScotT, J. W. 2014; FAludi, A. 2018).

A körülöttünk lévő táj ugyanakkor ezen a szubjektív lencsén keresztül válik kulturális tényezővé: ,a tájkép reprezentációként [értve] távolról sem 'objektív' valami: nincs előzetes jelentése, amelyet bármely tetszőleges közönség egyformán értene, éppen ellenkezőleg: értelmezések és újraértelmezések eredőjéből alakul ki” (DELL’AGNESE, E.-AMILHAT SZARY, A-L. 2015, p. 7).

Itt jön a képbe a kulturális távolság (cultural distance) koncepciója. „Az eltérő kultúrából származó emberek eltérő érzékelési világok lakói... Nemcsak eltérő módon strukturálják a tereket, hanem eltéróen tapasztalják is meg, mivel az idegrendszerük eltérően van 'programozva'..." - írja EDWARD T. HALLS, a proxemika elméletének megalkotója (1968, p. 84). Bár az emberi létezők térbeli viselkedése jelentôs mértékben megegyezik számos állatfajéval, a tér interpretációja révén ezt a viselkedést átszövi egy új, kulturális dimenzió.

A kulturális távolság érzete ekképpen a kultúrák közötti különbségek objektivációiból táplálkozik: a jelképekből (symbols), értékrendszerekből (patterns of values), normákból (norms) és szokásokból (habits), amelyek minden nemzetet másként jellemeznek (VAN Houtum, H. 2000). A politikai-adminisztratív határok ugyanakkor a legtöbb esetben nem esnek egybe a kulturális határokkal. Bár a modern nemzetállamok mindig is törekedtek az etnikai homogenizációra (ACTON, L.J. 1991; MiLl, J. S. 2006; DiENER, A.C.-HAGEN, J. 2012), azon belül a kulturális teljesítmények orientálására (AEBR 2011), az országhatárok mentén még zárt határrezsim esetén is kapcsolati zónák alakultak ki, ahol a kultúrák között megindult a kommunikáció, a csere (WASSENBERG, B. et al. 2015).

Ebből következik, hogy ha egy határ etnikailag (LADOS M. 2006), nyelvileg (BALTÀ PorTOLÉs, J. 2015), vagy történeti és kulturális identitását tekintve (MEZEI I. 2004; PlOAE, 
C. 2017) egységes vagy nagyon hasonló közösségeket választ el egymástól, az együttmúködés intenzitása és hatékonysága mindig magasabb fokú, mint olyan határok esetében, amelyek eltérő kulturális közösségek között alakulnak ki. Különösen igaz ez a tétel a Kárpátmedencére, ahol az első világháborút lezáró békeszerződések , gazdasági-társadalmi, infrastrukturális és etnikai értelemben addigra már szervesen összetartozó térszerkezeti egységeket, régiókezdeményeket, sőt valóságos régiókat szabdaltak szét" (BARANYI B. 2014, p. 28). Az Európai Unió legambiciózusabb vállalkozása éppen az ilyen határok elválasztó hatásainak meghaladása, csökkentése.

\section{Az INTERREG a határon átnyúló integráció szolgálatában: eredmények és kudarcok}

Az INTERREG program 1989-ben indult útjára, az Egységes Okmány elfogadásának és a kohéziós politika reformjának időszakában, 14 kísérleti projekttel, jelképes, mai áron számolva 21000 eurós költségvetéssel (WASSENBERG, B. et al. 2015). A ma ismert támogatási rendszer az INTERREG III (2000-2006) idején alakult ki, azóta különül el a közvetlen határ menti (A - ez az ún. „CBC”), a nagyobb összefüggó térségeket támogató transznacionális (B - pl. a Duna Régió), valamint az EU egészét lefedő, a tudástranszfert segítő interregionális (C) ága az INTERREG-nek, amely 2007-tôl már nem Közösségi Kezdeményezés, hanem a Kohéziós Politika harmadik, majd 2014 óta második prioritási célkitǔzése (MedEIROS, E. 2018).

Bár a téma jelentősége láthatóan növekedett a Kohéziós Politikán belül, és a támogatási keret is nominálisan a tízszeresére bővült, az érintett programok száma 100-ra emelkedett, mégis mindeközben a prioritási területen belül az 58 határ menti együttmúködési program kerete az Európai Unió éves bruttó nemzeti jövedelmének mindössze 0,005\%-át teszi ki (2. táblázat).

2. táblázat - Table 2

Az INTERREG-programok története számokban

(WASSENBERG, B. et al. 2015, p. 32.)

History of the INTERREG programmes in figures

(WASSENBERG, B. et al. 2015, p. 32.)

\begin{tabular}{cccc}
\hline $\begin{array}{c}\text { INTERREG- } \\
\text { program }\end{array}$ & Idoszak & $\begin{array}{c}\text { Teljes keret (millió euróban, } \\
\text { reálértéken számolva) }\end{array}$ & $\begin{array}{c}\text { Programok } \\
\text { száma }\end{array}$ \\
\hline Kísérleti & 1989 & 0,021 & 14 \\
I & $1990-1993$ & 1,082 & 31 \\
II & $1994-1999$ & 3,500 & 59 \\
III & $2000-2006$ & 5,100 & 79 \\
IV & $2007-2013$ & 7,800 & 92 \\
V & $2014-2020$ & 10,100 & 100 \\
\hline
\end{tabular}

Az Európai Bizottság azzal a céllal indította útjára az INTERREG-et 1990-ben, „hogy lendületet adjon együttmúködő hálózatok létrehozásához és fejlesztéséhez a belsô határokon keresztül, és hogy ezeket a hálózatokat átfogóbb közösségi hálózatokhoz kapcsolja" (van Houtum, H. 1999, p. 330). 
Mivel alapvetően területi fókuszú programról van szó, az INTERREG CBC világát egyfajta kettósség jellemzi, ami részben indokolja is relatív eredménytelenségét: egyrészt (főként a Barca Report 2009-es publikálása óta) a helyi szereplők egyfajta helyi-regionális eszközként tekintenek rá, amelynek segítségével megvalósíthatják (jó esetben) közös, határon átnyúló fejlesztési elképzeléseiket; másrészt uniós programként és a Kohéziós Politika második prioritási célkitúzéseként a közös EU-s célokat kellene szolgálnia.

A két megközelítés között WASSENBERG, B. et al. (2015) az alábbi meghatározással teremti meg az összhangot: „,[a határon átnyúló együttmúködés] ...nem egy egyszerú partnerség a helyi önkormányzatok között: ez egy eszköz nemcsak a természeti, politikai és kulturális határok leküzdéséhez, de a pszichikai határok meghaladásához és elválasztó erejük csökkentéséhez is" (p. 11).

Kétségtelen, hogy a határon átnyúló együttmúködési programok 1990 óta számos eredményt felmutathatnak: hozzájárultak a tudásmegosztáshoz, együttmúködési struktúrák kialakításához, a többszintú kormányzás modelljeinek terjedéséhez, a határon átnyúló nagyvárosi övezetek integrációjához, a határon átnyúló regionalizmus új formáinak kialakulásához (MEDEIROs, E. 2018). Az INTERREG-programok jóvoltából számos határ változott elválasztó vonalból interakciók helyszínévé (REITEL, B. et al. 2018), és nehéz volna vitatni, hogy a pénzügyi támogatás nélkül igen gyakran semmiféle határon átnyúló együttmúködést nem lehetne tapasztalni az adott határszakaszon.

Ugyanakkor számos szakértó és uniós elemzés rámutat a programok kudarcaira is. Nyilvánvaló, hogy a jelképesnek nevezhető pénzügyi keret nem elegendő ahhoz, hogy látványosan változtasson a határtérségek integráltságán, vagy oldja periférikus helyzetüket, viszont a szúkös keretek felhasználása sem optimális. Előfordul, hogy a CBCtámogatás csak a helyi költségvetést erősíti ,,anélkül, hogy valódi együttmúködésre ösztönözne" (Sсотт, J. W. 2014, p. 12). Az esetek döntő százalékában a határon átnyúló együttmúködés a projekt idejére koncentrálódik, az eredmények tartós fennmaradásában a partnerek már nem érdekeltek (EC 2007, 2016a, 2016b), az egy régióba tartozó szereplők saját agendát követve (LEIBENATH, M. et el. 2008) a szúkös forrásokért folytatott verseny közepette a többi térségi szereplőben konkurenciát látnak, nem partnert (DURAND, F. 2015).

A határon átnyúló fejlesztéssel foglalkozó szakértők és kutatók széles körben osztják azt a nézetet, hogy a határon átnyúló programok kudarcaira az integrált megközelítés jelentheti a megoldást. Ennek az integrációnak különböző értelmezései ismertek. Egyes szerzők a határon átnyúló interakciók számából, intenzitásából következtetnek az integráltság fokára (MARTínez, O. J. 1994; HARDi T. et al. 2009). Mások a határon átnyúló kapcsolatok, hálózatok számosságára és erósségére helyezik a hangsúlyt (SvENSSON, S.-NORDLUND, C. 2015; Decoville, A.-Durand, F. 2018). Ismét mások a határtérségben élők percepcióit tekintik meghatározónak, hogy ti. milyen mértékben veszíti el a határ a szerepét az o mentális térképükön (Miosga, M. 2008; Decoville, A.-Durand, F. 2018). Utóbbiak ebből a szempontból kulcsfontosságúnak tartják a határon átnyúló integrált tervezést, amely alkalmas arra, hogy „,kialakítsa egy közös határon átnyúló lakótérség (living area) érzését" (Decoville, A.-Durand, F. 2018, p. 234). Az integrált tervezés egyes régiók számára ,jó lehetőséget teremt arra, hogy javítsák vonzerejüket, és előtérbe helyezzék azokat az előnyöket, hogy különböző területi rendszerek interface-eként múködnek; vagy hogy pozitívan változtassák meg térségük image-ét, egy új identitás vagy brand kialakítása révén" (kiemelés tôlünk - a szerzók $)$. E tekintetben a kulturális együttmúködésnek megint csak meghatározó szerepe van: „A szocio-kulturális kohézió eróssége képes biztosítani a határon átnyúló együttmúködés tartósságát még az EU-s támogatások hiányában is" (BALTÀ PoRTOlÉS, J. 2015, pp. 21-22). 


\section{A határon átnyúló kultúragazdaság változó keretfeltételei}

A kultúragazdaságnak nincs egységes meghatározása. HoRKHEIMER és ADORNO 1944ből származó, a kultúripart kárhoztató híres tanulmányától (HORKHEIMER, M.-ADORNO, T. W. 1990) a közelmúlt kreatív ipari elméleteit felvázoló népszerú múvekig (pl. RICHARD FLORIDA The creative class címú munkája [2002] vagy a JOHN HARTLEY által szerkesztett Creative industries címú kötet [2005]) a szerzők a kultúra és a gazdaság közötti bonyolult viszonyrendszer egyes összetevőit emelik ki, és a legtöbb esetben a kultúragazdasághoz vagy a kreatív gazdasághoz sorolható tevékenységek klasszifikációján keresztül igyekeznek érthetôvé tenni a fogalom jelentését.

A fogalom történetét bemutató tanulmányok (pl. HALL, P. 2000; STEFÁN K.-TRÓCSÁNYI A. 2012; KERESNYEI K.-EGEDY T. 2015) kiemelik, hogy a kultúragazdaság kialakulása és fejlődése elválaszthatatlan attól a folyamattól, ahogy a tudás, az információ és kreativitás egyre nagyobb szerepet kap az értéktermelési folyamatokon belül. Az ezredforduló óta az új jelenségre elsősorban a 'kreatív gazdaság', 'kreatív ipar' terminusokat használják, egyrészt mivel a jelenség értelmezési keretei fokozatosan kibővültek a szerzői jogi, kutatási-fejlesztési és infokommunikációs területekkel is, másrészt azért, hogy a magaskultúrán túli tevékenységi területek is beleférjenek a definícióba. Ilyenformán a kreatív gazdaság a kultúragazdaságnál szélesebb értelmezési horizonttal rendelkezik (KERESNYEI K.-EgEdY T. 2015).

Gazdaságfejlesztési szempontból Magyarországon és Szlovákiában is a kreatív ipari fejlesztések részeként jelennek meg a kulturális szolgáltatások, valamint az örökségmenedzsment kérdései. Szlovákiában 2011-ben készült koncepció, majd 2015-ben stratégia és akcióterv az ágazat fejlesztésére vonatkozóan. Ez egyfajta origóként kezeli a kulturális örökséget, amely egyszerre biztosít nyersanyagot és inspirációt a kreativitásnak (MKSR-MHSR 2014, 2015; CENTÁrovÁ, J. 2020). Magyarországon a 2006-os A szabadság kultúrája címet viselő koncepciót (BozÓKi A. et al. 2006) követően 2020 végén fogadták el a Kreatívipari stratégia 2020-2030 elnevezésû dokumentumot, amely jelen tanulmány készítésének idején teljes átdolgozáson esett át, így ma még nem látható, hogy a kulturális örökség menedzsmentjének nagyobb szerepet szán-e, mint a 2006-os dokumentum, amely a témát a második stratégiai területként kezelte, de jórészt csak általános elveket fogalmazott meg annak fejlesztésére vonatkozóan.

Ahogy láttuk, a határtérségek különleges szerepet játszanak a kulturális örökség továbbadása szempontjából, mivel a határok egyszerre látnak el exkluzív (szűrő) és inkluzív (kontaktusteremtő) funkciókat, sajátos kultúrtájakat eredményezve, ahol a kulturális csere feltételeinek javításával rendkívül termékeny, kreatív közeg alakítható ki. Az UNESCO Világörökségi Bizottságának definíciója szerint (idézi: ZsILINCSAR W. 2012, p. 132) a kultúrtájak ,jjellegzetes földrajzi térségek, amelyek a természet és az ember közös munkáját reprezentálják". Az a tény, hogy a kultúrtáj részben emberi tevékenység eredményeként jön létre, felveti azoknak a konstrukcióknak és diskurzusoknak a jelentőségét, amelyek ezeknek a tevékenységeknek a szabályozási és értelmezési kereteit adják. EsZENYI O. (2016) szerint: „A kultúra befolyásolja a gondolkodást és ezáltal a táj alakítását is, ezért a táj vizsgálata megmutathatja, hogyan gondolkodunk és hogy gondolkodásunkat esetlegesen milyen ideológiák befolyásolják” (p. 7). Másrészt viszont „,bármely örökség valamiféle konstrukció, melynek rendeltetése lényegében politikai koncepció eredménye" (Husz M. 2014, p. 65). Egy határtérség kulturális örökségének állapota és annak valorizációja ennek megfelelően világosan utal a két szomszédos ország közötti kapcsolatok helyzetére is. 
E tekintetben a magyar-szlovák viszonyt a fokozatos nyitás és közeledés jellemezte az elmúlt közel 30 évben, amióta északi szomszédunk önállóvá vált. Tény, hogy a szlovák nemzeti identitás alakításában meghatározó szerepet játszik az ezeréves magyar „elnyomásra” és „szenvedésre” alapozott narratíva (Kollai I. 2008; BALOGH P.-GYELNík T. 2019), és egészen a 2015-ös, közös platformot eredményező migrációs válságig számos konfliktus nehezítette az együttmúködést a bősi vízerőmú Duna-medret is érintő megépítésétől vagy a mečiari magyarellenes nacionalizmustól a magyarigazolványok majd az egyszerűsített honosítás bevezetésén keresztül olyan örökségpolitikai lépésekig, mint SólYOM LÁSZló kiutasítása a révkomáromi Szent István szobor átadási ünnepségéról, vagy legutóbb Ludovít' Štúr szobrának nagy visszhangot kiváltó párkányi leleplezése. Ugyanakkor BALOGH P. -Gyelník T. (2019) Miroslav BAHNÁt idézik, aki szerint míg 1996ban a válaszadók 40\%-a érezte úgy Szlovákiában, hogy Magyarország valós fenyegetést jelent a fiatal köztársaság számára, addig 2014-re ez az arány 5\%-ra csökkent. Számos gesztus, közös uniós fellépés, a szlovák rendőrök dél-magyarországi jelenléte a migrációs krízis alatt vagy a magyar orvoscsoport szlovákiai jelenléte a pandémiás országos szúrés idején jelzik, hogy a kulturális örökség közös menedzsmentjét biztosító diszkurzív háttér ma kedvezőbb, mint bármikor korábban.

Az országhatár elválasztó hatása jelentősen gyengült az uniós csatlakozásnak köszönhetően (az osztrák mellett épp a szlovák határ mentén figyelhető meg a legélénkebb mobilitás), és maga az uniós diskurzus is kedvező hatással van a közös kultúrtáji örökség integrált fejlesztésére a kultúragazdaság és a kulturális turizmus keretei között.

\section{Az integrált határon átnyúló kultúrtáji fejlesztések felé}

Az INTERREG EUROPE program támogatásával a vízhez kapcsolódó kulturális örökség valorizációját célzó projekt indult 2019 augusztusában 5 ország 7 partnerének részvételével WAter-linked heritage Valorization by developing an Ecosystem approach (röviden: WAVE) - azaz Vízhez kapcsolódó örökségvalorizáció ökoszisztéma alapú megközelítés fejlesztésével - címmel (részletek az Ister-Granum ETT honlapján érhetôk el magyarul és angolul is). A projekt a program prioritásainak megfelelően úgy vizsgál egy ágazati témát, hogy eközben uniós szakpolitikai eszközök javításához is hozzájárul. Az egyik ilyen eszköz a magyar-szlovák INTERREG CBC program: a projekt eredményeként ajánlások születnek annak érdekében, hogy a határ menti program minél hatékonyabban tudja segíteni a vízhez kapcsolódó kulturális örökségi elemek integrált fejlesztését. A megszülető dokumentumok összevethetősége érdekében a Delfti Műszaki Egyetem szakértői által kidolgozott módszertan alapján a helyi és regionális partnereknek (Aarhus Dániából, Breda Hollandiából, Ravenna Olaszországból, Alicante tartomány Spanyolországból, valamint az Ister-Granum ETT a magyar-szlovák határról) össze kellett állítani egy helyzetértékelő tanulmányt. A tanulmány célja az volt, hogy számba vegye az adott város vagy régió vízhez kapcsolódó kulturális örökségi elemeit, vizsgálja meg azok tervezési, szabályozási és fejlesztési környezetét, valamint az érintett uniós szakpolitikai eszköznek a témával kapcsolatos elemeit. A számbavétel érdekében minden partnernek létre kellett hoznia egy helyi támogató csoportot (HTCS), területi és ágazati szakértőkből. A 2022 júliusáig tartó pályázati időszakban a partnereknek a témát érintő ökoszisztéma alapú módszertant kell kidolgozniuk, és ez alapján egy a témába vágó akciótervet előkészíteniük, valamint az érintett szakpolitikai eszköz fejlesztéséhez kapcsolódó javaslatukat megtenni. A projekt második szakaszában az akcióterv megvalósítását is el kell kezdeni. Az Ister-Granum ETT helyzetértékelő tanulmánya 2020. áprilisra készült el, a helyi támogató csoport aktív közremúködésével (CESCI 2020). 
A projekt sikerét az eurorégióban több tényező is segíti. Egyrészt az Ister-Granum ETT térségének nagy része évszázadokon keresztül egy közigazgatási egységet alkotott, Esztergom vármegye keretein belül (BоTTLIK Zs. et al. 2019). Ugyanakkor maga az egykori főváros a mai Szlovákia nagy részét magába foglaló Esztergomi érsekség székhelyeként a vármegyénél nagyobb vonzáskörzettel rendelkezett. Bár ezt a vonzáskörzetet a trianoni békeszerződés csonkolta, a Mária Valéria híd 2001-es újranyitásával jelentős részben helyreállt (JASCHITZ M. 2010, 2019).

Előnyös adottság az is, hogy Esztergom és Párkány vonzáskörzetének lakossága túlnyomórészt magyar ajkú. A magyarok részaránya számos településen meghaladja a 80\%-ot,és a 2003-ban létrejött eurorégió területén mindössze négy olyan település található (Lekér - Hronovce, Peszektergenye - Sikenica, Kural - Kural'any és Zselíz - Želiezovce), ahol a szlovákság többséget alkot. Ugyanakkor a régióhoz tartozó pilisi falvakban még mindig számottevő szlovák közösség él (pl. Pilisszentkereszten, Pilisszentlászlón, Piliscséven és Pilisszentléleken). S bár a szlovákiai magyar nyelvhatár az utóbbi évtizedekben látványos mértékben mozdult el dél felé (FARKAS GY. 2019), a magyar nyelv még mindig dominánsnak mondható az ETT egész területén. Mindez azt jelenti, hogy az Ister-Granum ETT egy kulturálisan jelentős mértékben összetartozó térségben alakult ki, ami elméletileg kedvez a határon átnyúló integrált kulturális fejlesztéseknek.

További előnyös adottságként említhető meg, hogy a térségben a határon átnyúló együttmúködés intézményesülése szerves folyamatként ment végbe, viszonylag korán. A Mária Valéria híd újjáépítéséről szóló államközi szerződés 1999. szeptember 16-i aláírása után alig egy évvel a két határ menti kistérségi társulás (kiegészülve Tokod és Tokodaltáró önkormányzataival) már aláírta a regionális együttmúködésrőll szóló megállapodást. A Duna és a Garam nevét felvevő eurorégió 2003 novemberében alakult meg, összesen 100 önkormányzat részvételével Esztergom és Párkány központtal, a magyar fővárosi agglomeráció északi peremén. 2008. május 6-án pedig a tagönkormányzatok döntő többsége az Európai Unióban másodikként alapította meg az Ister-Granum Európai Területi Társulást (BOTTLIK Zs. et al. 2019). Az új intézményi forma a határon átnyúló integráció legmagasabb foka ma Európában, a teljes határtérséget reprezentáló szervezetként az ETT képes a térség integrált fejlesztéseit koordinálni (PINTÉR E. 2008), és ez szintén kedvező adottság, amikor a kulturális örökség határon átnyúló integrált menedzsmentjéről beszélünk.

Az ETT részvételével megvalósuló WAVE projekt keretében három tematikus csoportba (PILOT-ok) sorolva összesen 16 konkrét elképzelést sikerült beazonosítani, amelyek a régió vízhez kapcsolódó kulturális örökségét jelenítik meg és fejlesztik tovább. Az első PILOThoz (A víz arca) a víznek mint természeti jelenségnek a humanizálását célzó beruházások tartoznak. Az idesorolt esztergomi, párkányi és szobi Duna-partok magukon viselik a történelem nyomait, az egyes generációk tájalakító beavatkozásait, és azokat, illetve a víz és a polgárok viszonyát tematizálják, formálják és fogalmazzák újra. A második PILOT (A víz ereje) a víz építő és pusztító energiáit jeleníti meg. Egyrészt idesorolhatók a régió vízimalmai (amelyek közül háromnak az építészeti és funkcionális megújítása került be az akciótervbe); az esztergomi reneszánsz vízgép másolata (amely már látogatható), másrészt az esztergomi és párkányi vízjelek interaktív feldolgozása (ez utóbbiak a víz 1838-as pusztítására utaló árvízszintet jelző táblák). A harmadik PILOT-hoz (A víz szelleme) olyan kezdeményezések tartoznak, amelyek a vízhez kapcsolódó spirituális örökséget dolgozzák fel (múzeumok, vízhez kapcsolódó kulturális rendezvények). Az egyes projektelemek az eurorégió különböző térségeit érintik, a határ mindkét oldalán (1.ábra).

A HTCS aktív közremúködésével sikerült a három PILOT 16 projektjét egy közös beavatkozási logika mentén összefüzni, ami jelentősen megkönnyítette az akcióterv összeállítását (2.ábra). 


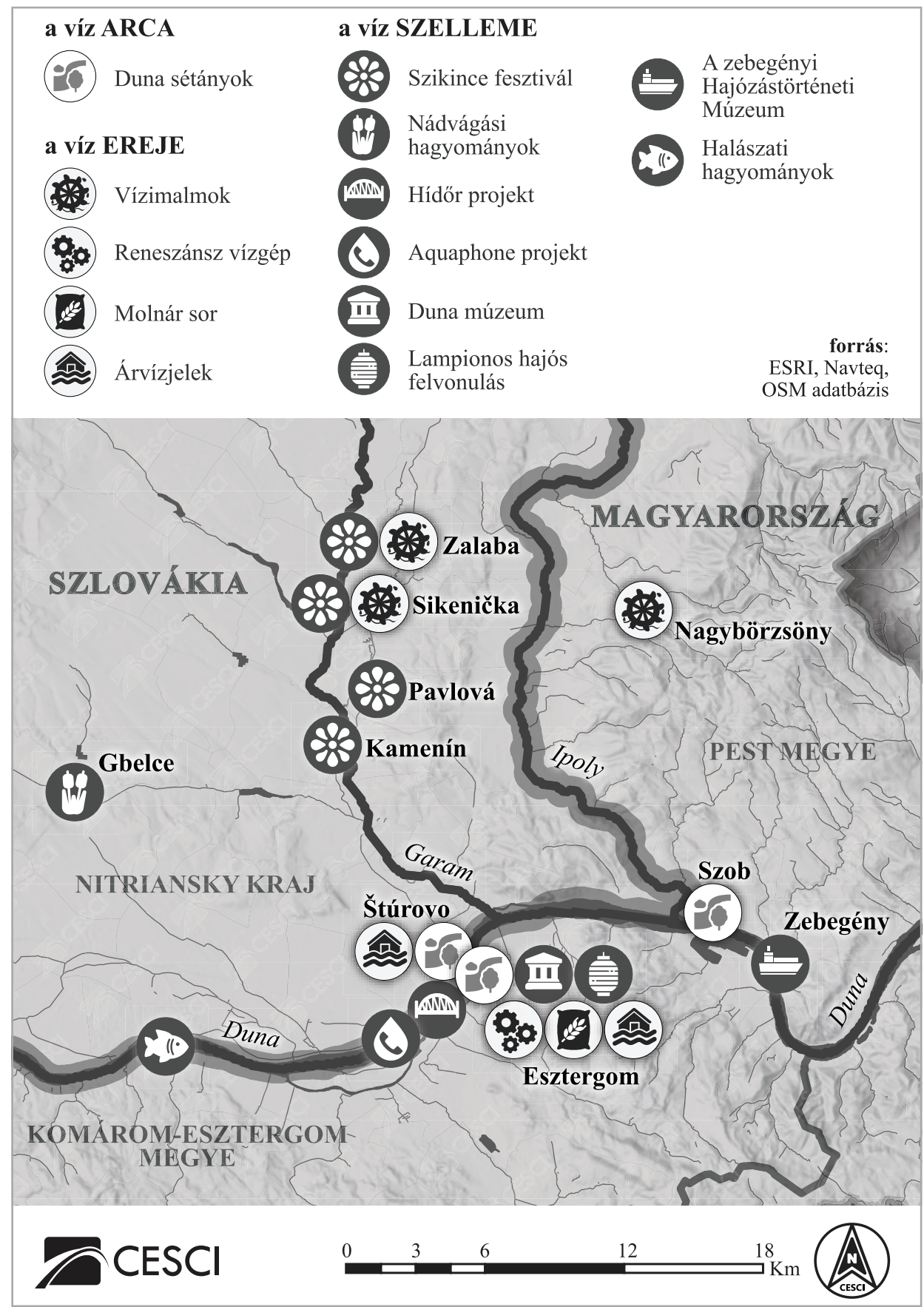

1. ábra A WAVE projekt keretében beazonosított kulturális beavatkozások térbeli elhelyezkedése (szerk. JÁNOSI V., CESCI)

Figure 1 Spatial pattern of the interventions identified within the framework of the WAVE project (ed. by JÁNOSI, V., CESCI) 


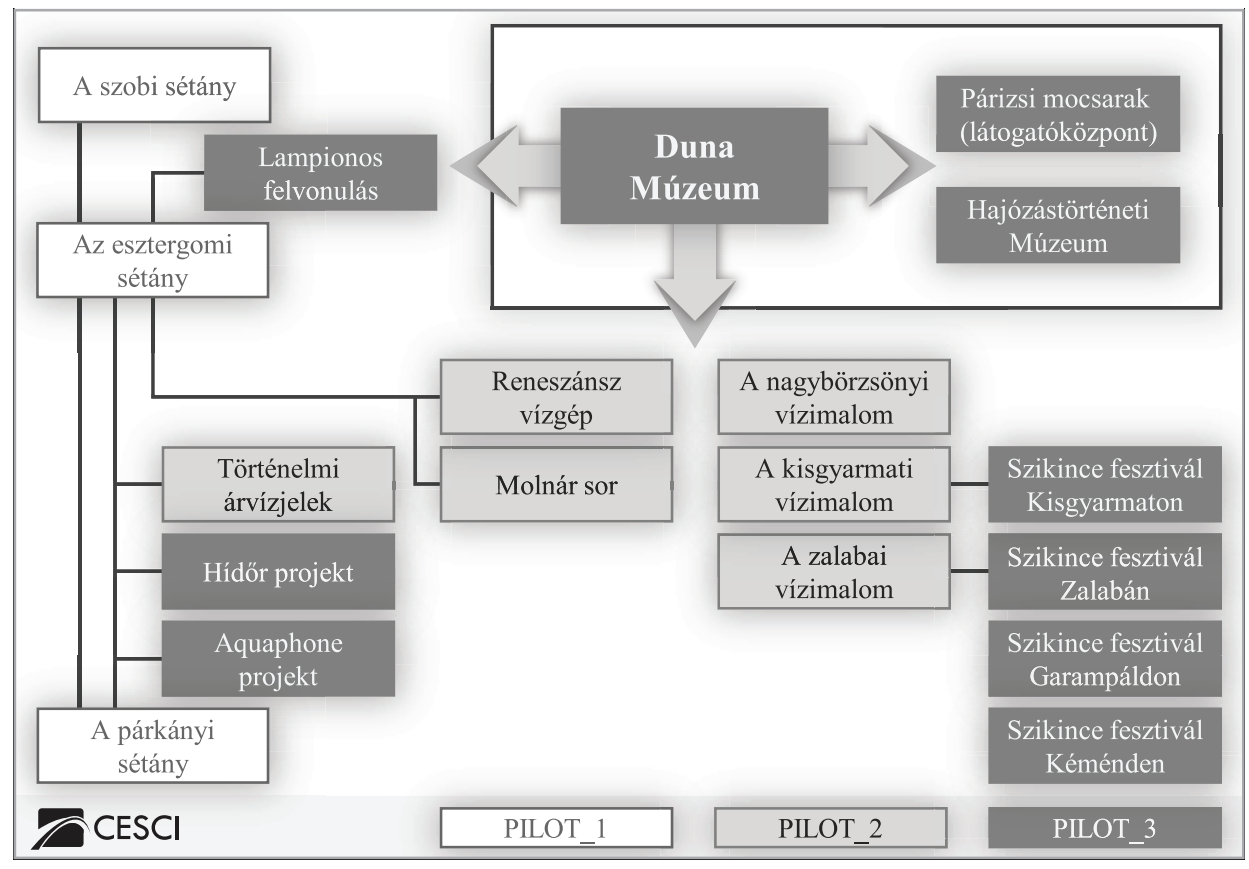

2. ábra A WAVE projektjeinek belső logikai összefüggése (szerk. JÁNOSI V., CESCI)

Figure 2 Internal logic of the WAVE projects (ed. by JÁNOSI, V., CESCI)

A tervezett fejlesztések középpontjában az esztergomi Duna Múzeum áll, ahol 2019ben nyílt meg az új, látványos interaktív Vízeum kiállítás, amely egyszerre reflektál a víz arcával, erejével és szellemével kapcsolatos örökségre; a regionális vonatkozások azonban csak érintőlegesen szerepelnek a kiállításon. Ezt a hiányosságot pótolhatja a magántulajdonú zebegényi hajózási múzeum, amelynek bővítése vagy új helyszínre költöztetése elkerülhetetlenné vált, valamint a ramsari besorolás alatt álló Párizsi-mocsár (Parížske močiare) élővilágára és a vízhez kapcsolódó életmódra összpontosító, régóta tervezett látogatóközpont a köbölkúti (Gbelce) Ardea nevű korábbi gyermek-üdülőközpontban. (A három múzeumhoz kapcsolódna az újabban javasolt Ipoly Múzeum, amely szintén átfogó módon dolgozná fel a jelenlegi határfolyó természeti és kulturális örökségét.) A múzeumok között szoros együttmúködés alakítandó ki a kiállítási tematikák tervezése, kiállítások megosztása terén.

A humanizált vízpartok fejlesztése nem kizárólag a Duna-parti sétányok kialakítását jelenti, jóllehet ezek a beavatkozások önmagukban is jelentősen javítják majd az érintett települések vízzel való kapcsolatát. Esztergomban az árvízvédelmi gát 2019-ben megkezdődött kiépítése teremti meg a lehetőségét annak, hogy a Kis-Duna sétány teljesen megújuljon. Ehhez a látványtervek már elkészültek. Párkányban a dunai korzó csak egy rövid szakaszon épült ki, a Mária Valéria híd és egy csónakház megszakítja, a város ezt a diszkontinuitást szeretné felszámolni, és a korzót nyugati irányban továbbépíteni. Szob esetében pedig a most meglévő, a kerékpárút által uralt vízpartot szeretnék polgári külsővel ellátni, csakúgy, mint a helyzetértékelés lezárását követően utólag javasolt karvai Duna-korzó esetében. Ugyanakkor a következő években sorra kerülő fejlesztések keretében egyben a WAVE során beazonosított kulturális örökségi elemek is beépítésre kerülnek. Párkányban pl. az egykori hídvámház helyett a Mária Valéria híd szlovákiai hídfőjében egy modern épületben 
kapna elhelyezést a Párkány és Vidéke Kulturális Társulás által menedzselt Hídőr projekt kiállítási helyszíne, az esztergomi új Kis-Duna korzón pedig az eurorégió vízhez kapcsolódó kulturális örökségi elemeit megjelenítő élményszerú utalások kerülnének beépítésre. Ugyancsak az esztergomi Kis-Duna biztosít helyszínt minden április 30-án a hajózási évadnyitó rendezvénynek, az ún. lampionos felvonulásnak, ami a debreceni virágkarneválhoz hasonlóan egyedi összeállítású úszó alkalmatosságok látványos leúsztatását jelenti. Az Aquaphone projekt minden év június elején a kortárs múvészet eszközeivel eleveníti fel azt az időszakot, amikor a határ két oldalán elszakítottságban élő családok esténként szélcsendes időben a Duna vize fölé hajolva kommunikáltak egymással a határon át. Az említett Hídór projekt keretében pedig 3-6 hónapos idôszakra fogad Párkány nemzetközi múvészeket, akik ott-tartózkodásuk ideje alatt múalkotásokkal, performanszokkal szimbolikusan „orzik a hidat”, hogy az újraalkotott kapcsolatok ne szakadjanak meg többé.

A Garam mellékfolyásáról elnevezett Szikince fesztivál egy színes kulturális rendezvénysorozat, amely a patak mentén elhelyezkedő négy települést, valamint a Garamon található Szerelem-szigetet öleli fel (utóbbin a rendezvények lebonyolításához szükséges állandó infrastruktúra épülne ki). Szerencsés egybeesés, hogy az eurorégió még álló négy vízimalma közül kettő is a fesztiválnak helyet adó településeken, Kisgyarmaton (Sikenička) és Zalabán található. A HTCS szakértőinek javaslatai alapján ezek a malmok felújításukat követően új funkciókat kapnak, és a nagybörzsönyi, ma is látogatható vízimalommal közös témaút részeit fogják képezni (utóbbi esetében a vízmeghajtáshoz szükséges infrastrukturális átalakításokra kerülhet sor). A vízi kerék révén kapcsolódnak a fenti beavatkozások az esztergomi reneszánsz vízgéphez, amely egy a középkorban ritkaság számba menő mechanikai megoldással biztosította a vár vízellátását a Duna melletti forrásból. A vízgép másolata 2019 óta látogatható a rekonstruált Veprech-toronyban, amely ráadásul a Molnár sor, az esztergomi molnárok egykori utcájának szomszédságában található. Az utca lehetőséget biztosítana a történelmi hagyományok megjelenítésére is.

Mint a fenti ismertetôből kiderül, a tervezett beavatkozások között többszörös szinergikus összefüggésrendszer áll fenn. A WAVE projektnek köszönhetően sikerült egy olyan narratívát megalkotni, ami a DURAND, F. (2015) által említett területi versengésben részt vevő szereplők szándékait közös csatornába terelte, bevonva számos, a határon átnyúló együttmúködésben közvetlenül érdekeltek körén kívül álló partnert. Az elszigetelt projektelképzeléseket sikerült egy koherens, területi szempontból is integrált egésszé alakítani, hosszú távon fenntartható, határon átnyúló tartalmakkal. Mindez azt jelenti, hogy az INTERREG CBC programok és projektek fent említett gyengeségeit sikerült átfogóan kezelni.

A megvalósításhoz ugyanakkor számos további tényező együttes fennállása szükséges. Amennyiben ugyanis a hagyományos módon kell az egyes projektekhez támogatást szerezni (fôként) az INTERREG CBC programból, az a most együttmúködő partnerek közötti rivalizálást fogja eredményezni. A remélt szinergiák akkor alakulhatnak ki, hogyha az egyes fejlesztések egymást segító módon, egymással párhuzamosan valósulhatnak meg. Ehhez volna szükség a projektek csomagban történő versenyeztetésére, amire a jelenlegi SKHU INTERREG CBC program is lehetőséget kínál, a foglalkoztatási célú akciótervek (territorial action plan for employment, TAPE) eszközén keresztül.

A TAPE a szlovák-magyar INTERREG V-A program tervezésekor merült fel lehetőségként, az olasz-francia ALCOTRA program keretében alkalmazott határon átnyúló integrált terv (plan intégré transfrontalier, PIT) mintájára, az Európai Unió által preferált integrált területi beruházással (Integrated Territorial Investment, ITI) szemben. Az ITI lényegében azt tenné lehetôvé, hogy egy adott térség speciális kihívásaira integrált választ lehessen adni, a rendelkezésre álló, eltérő alapokhoz tartozó források kombinációjával (KocLUBA, D. 2018); ezáltal az ITI mint területi eszköz orvosolhatja az ágazati operatív programok és 
általában a Kohéziós Politika „területi vakságát”. Ugyanakkor a több alapból megvalósuló (ún. multi-fund) finanszírozás feltételezi az egyes alapok menedzsmentjei által közösen kialakított kiválasztási, finanszírozási és monitoring mechanizmusok alkalmazását, ami határon átnyúló kontextusban aránytalan mértékben bonyolítja meg az ilyen beavatkozások adminisztrációját és végrehajtását.

A tervezés során ezért esett a választás az olasz-francia határon a 2007-2013-as időszakban már használt PIT-re. Ennek lényege, hogy a helyi szereplők az együttmúködési program által meghatározott prioritási területekhez kapcsolódóan integrált térségi tervet készítenek, amelyek 2-5, egymással szinergikusan összekapcsolódó projektet tartalmazhatnak, és ezeket egymással párhuzamosan valósítják meg. Egy további projekt keretében kell biztosítani a partnerek közötti koordinációt és a teljes PIT kommunikációját (ALCOTRA 2007).

A TAPE a magyar-szlovák határ mentén a program 3. prioritási tengelyén belül segíti elő a határon átnyúló munkaerő-mobilitást és a minőségi munkaerópiac kialakulását. Ennek érdekében összesen 2-7 foglalkoztatási célú és egy koordinációs és kommunikációs projektet tartalmazhat. A foglalkoztatási tematikájú projektek célja a munkahelyek létrehozása, a határ menti munkaerópiacok integrációja, a minőségi munkaeró biztosítása. A kiválasztásra került 9 TAPE ennek megfelelően KKV-k munkahelyteremtő beruházásait, barnamezős önkormányzati területek rehabilitációját, fejlesztését, a szakképzési infrastruktúrát és a társadalmilag marginalizált rétegeknek a munkaerópiacra való eljutását stb. támogatja. Bár a modell alkalmazásával kapcsolatos tapasztalatok vegyesek, az már most látható, hogy egyes esetekben az adott határtérség gazdasági és munkaerőpiaci fejlesztéséhez a TAPE-ek érzékelhető mértékben képesek hozzájárulni.

Az eszközt (a foglalkoztatási orientációt mellőzve) ezért alkalmasnak látjuk arra is, hogy a WAVE keretében beazonosított fejlesztési elképzelések nagy részét integrálva járuljon hozzá az Ister-Granum eurorégió kultúragazdaságának integrált fejlesztéséhez. Maguk a projektek is segítik az elmúlt évszázadban vitathatatlanul kialakult kulturális távolság csökkentését, a kulturális örökség tematizációját és valorizációját. Ugyanakkor az egyes helyi kezdeményezések térségi integrációja révén számos további eredményt is el lehet érni. Egyrészt direkt módon lehet rámutatni a közös örökség egymást erősítő elemeire, és ezeket sajátos összefüggésrendszerükben lehet prezentálni az ide látogatóknak és a régió lakosságának egyaránt. Másrészt a kezdeményezők egy integrált beavatkozás révén a határon átnyúló közösségépítésnek is aktív szereplőivé válnak. Ennek a közösségépítésnek fontos szerepe van abból a szempontból is, hogy a térségi kultúragazdaság szereplői, köztük a kreatív iparhoz sorolható vállalkozók nem kizárólag indirekt módon, kivitelezőként tudnak bekapcsolódni a fejlesztések megvalósításába, hanem közvetlenül is részt tudnak venni a HTCS keretein belül a program további alakításában, formálásában. A kultúragazdaság határon átnyúló integrált fejlesztése áttételesen hatással lesz az iskolai oktatásra, nevelésre, valamint az eurorégió rendezvénykínálatára is, és így a kezdeményezés segíteni fog a kognitív, mentális, érzelmi és kulturális határok lebontásában is. Harmadrészt a kulturális örökségi helyszínek összekapcsolásával megfogalmazható egy közös narratíva is, amelynek hosszú távon identitásképző ereje is lehet, fölülírva a történelem viharaiban kialakult körülmények elválasztó hatásait (PlOAE, C. 2017).

\section{Összefoglalás}

Tanulmányunkban azt a problémát jártuk körül, hogy mivel magyarázható, hogy a magyar-szlovák határon az elmúlt 25 évben kulturális tematikájú fejlesztésekre felhasznált jelentős mennyiségű forrás ellenére nem figyelhető meg a határtérség kohéziójának lát- 
ványos erősödése. Érvelésünket egyrészt a szubjektív távolságra vonatkozó „határtani” (border studies) vizsgálatokra alapoztuk, amelyek egyik fő következtetése, hogy a kognitív, mentális, érzelmi és kulturális távolság mértékét a határtérségekben jelentősen befolyásolja az etnikai, nyelvi, kulturális összetartozás szintje, a közös múlt öröksége. A magyar-szlovák határ, ahogy arra számos szakértő felhívta az utóbbi évtizedekben a figyelmet, korábban szervesen összetartozó kis- és középtájakat, kulturálisan szorosan összetartozó közösségeket választott szét, természetes városi vonzáskörzeteket darabolt fel. Ez a közös örökség, a magyar nyelv máig meglévő dominanciája, valamint a közös kultúrtáji örökség kedvező feltételei lennének a kultúragazdaság határon átnyúló integrált fejlesztésének. Ehhez ráadásul az INTERREG program megfelelő finanszírozási hátteret is biztosítana.

Az eddig a térségben megvalósított, a témába vágó fejlesztések ugyanakkor elszórtan jelentkeztek, és az egyes projektek tartalmilag és kormányzási szinten sem kapcsolódtak egybe szinergikus egésszé. Ezért jutottunk arra a következtetésre, hogy a jövőben a kulturális projekteket integráltan kellene megvalósítani, mivel ezáltal rajzolódhat ki az a koherens narratíva, amely akár a térségi identitás alakítására is képes hatást gyakorolni, csökkentve a határ két oldalán élők közötti szubjektív távolságérzetet.

Az Ister-Granum ETT részvételével megvalósítás alatt álló WAVE-projekt egyik fó célja éppen az, hogy a vízhez kapcsolódó kulturális örökség valorizációjának apropóján segítse olyan szakpolitikai eszközök fejlesztését, amelyek hatékonyabbá tehetik az uniós források felhasználását. A térséget érintő szlovák-magyar INTERREG V-A program keretében 2014 és 2020 között alkalmazott területi akcióterv megfelelő eszköz a kultúragazdasági fellépések integrációjára, amennyiben 2021 után, az új programozási időszak alatt is használni tervezik, és használatát kiterjesztik a foglalkoztatáson kívüli témákra is. A WAVE címú projekt keretében megkezdett tervezési munka összesen 16 térségi beavatkozás szinergikus összekötését teszi lehetôvé, amelyek megvalósításának koordinációját az ETT el tudná látni, biztosítva ezáltal a fejlesztések közötti koherenciát is.

Összegzésképpen megállapítható, hogy a határon átnyúló kultúragazdaság integrált fejlesztésének a feltételei Esztergom és Párkány térségében kedvezők, az ehhez szükséges eszközök rendelkezésre állnak, mindössze a meglévő kormányzási kapacitást kellene hatékonyabban kihasználni a térségi szereplők közötti koordináció és az egyes kezdeményezések közötti összhang erősítésére. Ezáltal látványosan javítható a beavatkozásoknak és az uniós források felhasználásának a hatékonysága, miközben a határtérségben élők szubjektív idegensége is csökkenni fog.

OCSKAY GYULA

Határon Átnyúló Kezdeményezések Közép-európai Segítő Szolgálat, Budapest

gyula.ocskay@cesci-net.eu

HARDI TAMÁS

KRTK RKI Nyugat-magyarországi Tudományos Osztály, Győr

hardi.tamas@krtk.hu

IRODALOM

ACTON, L. J. 1991: Nacionalizmus. - In: LudAssy M. (szerk.): Az angolszász liberalizmus klasszikusai I. Atlantisz, Budapest. pp. 120-152.

AEBR 2011: European Charter for Border and Cross-border Regions.

http://www.aebr.eu/files/publications/110915_Charta_EN_clean.pdf (letöltés: 2020. július 7.)

Agnew, J. 2008: Borders in the mind: re-framing border thinking. - Ethics \& Global Politics 1. 4. pp. $175-191$. 
ALCOTRA 2007: Programme de coopération transfrontalière France-Italie ALCOTRA 2007-2013. Programme opérationnelle. http://www.espaces-transfrontaliers.org/fileadmin/user_upload/documents/Programmes_ europeens/PO_ALCOTRA.pdf (letöltés: 2020. július 7.)

ÁSZ 2008: Jelentés az INTERREG célú költségvetési előirányzatok hasznosulásának ellenőrzéséről. - Állami Számvevőszék, Budapest. 30 p.

BALOGH P.-GYELNÍK T. (2019): Hungarian and Slovak national narratives with a focus on the shared boundary. - In: Bottlik Zs.-Gyelník T.-OcskAY Gy. (szerk.): Changes in the representation of a borderscape. The case of the Mária Valéria Bridge. Central European Service for Cross-Border Initiatives, Budapest. pp. 65-86.

BAltà Portolés, J. 2015: Cross-border cooperation and cultural communities in Europe. - Centre Maurice Coppieters, Brussels. 60 p.

BARANYI B. 2014: Adalékok a határ mentiség újraértelmezéséhez Magyarországon. - Deturope - The Central European Journal of Regional Development and Tourism 6. 2. pp. 26-45.

Bottlik Zs.-Nagy P.-Pete M.-Telbisz T. (2019): Glosses on the Ister-Granum EGTC research. - In: BotTLIK Zs.-Gyelník T.-OCskAy Gy. (szerk.): Changes in the representation of a borderscape. The case of the Mária Valéria Bridge. Central European Service for Cross-Border Initiatives, Budapest. pp. 87-108.

Bozóki A.-SEbók M.-Hunyadi Zs.-Husz D. - InKei P.-KARSAi Gy.-KitZinger D.-SÜKÖSD M.-TÖRÖK A. -VÖRÖs M.-Wessely A. 2006: A szabadság kultúrája. Magyar kulturális stratégia 2006-2020. Budapest. http://www.nefmi.gov.hu/kultura/2006/szabadsag-kulturaja (letöltés: 2021. február 9.)

CEnTÁrová, J. 2020: Creative economy as a tool of competitiveness. - SHS Web of Conferences 83, 01007. Current Problems of the Corporate Sector 2020. https://doi.org/10.1051/shsconf/20208301007 (letöltés: 2021. január 21.)

Cerdeiras, A.-Pinheiro, B.-VAreiro, L.-Mendes, R. 2018: Tourism and valorisation of cultural heritage: The case of the Castle of Lanhoso. - Tékhne 16. 2. pp. 28-37. https://doi.org/10.2478/tekhne-2019-0010

CESCI 2020: WAVE. Regional Status Quo. Ister-Granum European Grouping of Territorial Cooperation. Central European Service for Cross-Border Initiatives, Budapest. 53 p,

Decoville, A.-Durand, F. 2018: Exploring cross-border integration in Europe: how do populations cross borders and perceive their neighbours? - European Urban and Regional Studies 26. 2. pp. 134-157.

Dell'Agnese, E.-Amilhat SzARy, A-L. 2015: Borderscapes: from border landscapes to border aesthetics. - Geopolitics 20. 1. pp. 4-13.

Diener, A.C.-HAGEn, J. 2012: Borders. A very short introduction. - Oxford University Press, New York. 137 p.

DuRAND, F. 2015: Theoretical framework of the cross-border space production - the case of the Eurometropolis Lille-Kortrijk-Tournai. - Journal of Borderlands Studies 30. 3. pp. 309-328.

EC 2007: Phare Ex Post Evaluation. Phase 3. Thematic Evaluations - Cross-Border Cooperation. Thematic Evaluation. Phare Cross-Border Cooperation Programmes 1999-2003. - European Commission, Brussels. 54 p.

EC 2016a: Ex-post evaluation of Cohesion Policy programmes 2007-2013, focusing on the European Regional Development Fund (ERDF) and the Cohesion Fund (CF). Final report. Main report. - European Commission, Brussels.

EC 2016b: Ex post evaluation of Cohesion Policy programmes 2007-2013 financed by the European regional development Fund (ERDF) and Cohesion Fund (CF). Case study: Hungary-Slovakia Cross-border Cooperation Programme 2007-2013. - European Commission, Brussels. 50 p.

EsZENYI O. 2016: A kultúrtáj értelmezésének változása a kultúrföldrajzban. - Földrajzi Közlemények 140. 1. pp. 1-12.

FALUDI, A. 2018: The poverty of territorialism. A neo-medieval view of Europe and European planning.-Edward Elgar Publishing, Cheltenham-Northampton. 200 p.

FARKAS GY. (2019): Linguistic and ethnic border changes within the frames of Ister-Granum Euroregion settlement group. - In: Bottlik Zs.-Gyelní T.-OcskAY Gy. (szerk.): Changes in the representation of a borderscape. The case of the Mária Valéria Bridge. Central European Service for Cross-Border Initiatives, Budapest. pp. 129-165.

HaLl, P. 2000: Creative cities and economic development. - Urban Studies 37. 4. pp. 639-649.

Halls, E.T. 1968: Proxemics. - Current Anthropology 9. 2-3. pp. 83-95.

HARdi T.-HAJdú Z.-MEZEi I. (szerk.) 2009: Határok és városok a Kárpát-medencében. - MTA Regionális Kutatások Központja, Győr-Pécs. 374 p.

Horkheimer, M.-Adorno, T. W. 1990: A kultúripar. - In: Horkheimer, M.-Adorno, T. W.: A felvilágosodás dialektikája. Filozófiai töredékek. Gondolat - Atlantisz. pp. 147-200.

Husz M. 2014: Az örökségrekonstrukciók geopolitikai kerete. - Földrajzi Közlemények 138. 1. pp. 64-73.

JASCHITZ M. 2010: Elzárt múlt - határtalan jövő? Esztergom vonzáskörzete a huszadik században és az ezredfordulón. - Tér és Társadalom 24.3. pp. 93-135.

JASCHITZ M. 2019: (Re)birth of a twin city. Hinterland analysis in the region of Esztergom-Štúrovo. - In: BotTlik Zs.-Gyelník T.-OCsKAy Gy. (szerk.): Changes in the representation of a borderscape. The case of the Mária Valéria Bridge. Central European Service for Cross-Border Initiatives, Budapest. pp. 109-128. 
Keresnyei K.-Egedy T. 2015: Adalékok a kreatív gazdaság elméletéhez. - Földrajzi Közlemények 139. 1. pp. 30-42.

KoCLUBA, D. 2018: Implementation of integrated territorial investments in Poland. Rationale, results and recommendations. - Quaestiones Geographicae 37. 4. pp. 81-98.

Kollai I. 2008: A szavak ereje. - In: Kollai I. (szerk.): Meghasadt múlt. Fejezetek a szlovákok és a magyarok történelméből. Terra Recognita Alapítvány, Budapest. pp. 19-29.

LADOS M. 2006: Az INTERREG-PHARE CBC projektek típusai és tapasztalatai. - In: KAISER T. (szerk.): Hidak vagy sorompók? A határon átívelő együttmúködések szerepe az integrációs folyamatban. - Új Mandátum, Budapest. pp. 204-229.

Leibenath, M.-Korcelli-Olejniczak, E.-Knippschild, R. 2008: Bridging the gap? - In: Leibenath, M. -KorCELli-OleJNiCZAK, E.-KNiPPSChILD, R. (szerk.): Cross-border governance and sustainable spatial development. Springer, Berlin-Heidelberg. pp. 187-193.

Lösch, A. 1954: The economics of location. - Yale University Press, New Heaven. 320 p.

MartíneZ, O. J. 1994: The dynamics of border interaction: new approaches to border analysis. - In: SCHOFIELD, C. H. (szerk.): Global boundaries. Routledge, London-New York. pp. 1-15.

MedeIros, E. 2018: The role of European Territorial Cooperation (ETC) in EU Cohesion Policy. - In: MEDEIROS, E. (szerk.): European Territorial Cooperation. Theoretical and empirical approaches to the process and impacts of cross-border and transnational cooperation in Europe. Springer, Cham. pp. 69-93.

Medve-BÁlint G. 2013: Incentives and obstacles to cross-border cooperation in post-communist Central Europe. - In: BELLINI, N.-HILPERT, U. (szerk.): Europe's changing geography. The impact of inter-regional networks. Routledge, London. pp. 44-70.

MEZEI I. 2004: A magyar-szlovák határ menti kapcsolatok esélyei. Ph.D. értekezés. - Debreceni Egyetem Földtudományi Doktori Iskola, Debrecen. 183 p.

MiLl, J. S. 2006: Considerations on representative government. http://oll.libertyfund.org/?option=com_staticxt\&staticfile=show.php\%3Ftitle=234\&chapter=16569\&layout =html\&Itemid=27 (letöltés: 2014. február 27.)

Miosga, M. 2008: Implication of spatial development policies at European and national levels for border regions. The case of Germany. - In: Leibenath, M.-KorCElli-OlejnicZAK, E.-KnipPschild, R. (szerk.): Cross-border governance and sustainable spatial development. Springer, Berlin-Heidelberg. pp. 15-31.

MKSR-MHSR 2014: Návrh. Stratégia rozvoja kreatívneho priemyslu v Slovenskej republike. - Ministerstvo kultúry Slovenskej republiky a Ministerstvo hospodárstva Slovenskej republiky, Bratislava. https://www.culture.gov.sk/wp-content/uploads/2019/12/strategia.pdf (letöltés: 2021. február 9.)

MKSR-MHSR 2015: Návrh. Akčný plán realizácie Stratégie rozvoja kreatívneho priemyslu v Slovenskej republike. - Ministerstvo kultúry Slovenskej republiky a Ministerstvo hospodárstva Slovenskej republiky, Bratislava. https://www.culture.gov.sk/wp-content/uploads/2019/12/akcny_plan.pdf (letöltés: 2021. február 9.)

NiJkAMP, P.-RieTVELd, P.-SAlOMON, I. 1990: Barriers in spatial interactions and communications: a conceptual exploration. - The Annals of Regional Science 24. 4. pp. 237-252.

PINTÉR E. 2008: Standard jogi modell határon átnyúló regionális együttmúködésekre. Doktori értekezés. - Széchenyi István Egyetem Állam- és Jogtudományi Doktori Iskola, Győr. 224 p.

PloAe, C. 2017: Cultural influences in cross border cooperation. An overview on Romania-Serbia cross border EU financed programme. - Proceedings of the International Conference on Business Excellence 11. 1. pp. 616-624.

RAJARAM,P. K.-GRUNDY-WARR, C. 2007: Introduction.-In: RAJARAM, P. K.-GRUNDY-WARR, C. (szerk.): Borderscapes. hidden geographies and politics at territory's edge. University of Minnesota Press, Minneapolis -London. pp. ix-1x.

RAKitovac, K. A.-URošEvić, N. 2017: Valorisation of Cultural Heritage in Sustainable Tourism. - Management 12. 3. pp. 199-215. https://doi.org/10.26493/1854-4231.12.199-215

Reitel, B.-WASSEnBerg, B.-PEYRONY, J. 2018: The INTERREG experience in bridging European territories. A 30-year summary. - In: MedEIRos, E. (szerk.): European territorial cooperation. Theoretical and empirical approaches to the process and impacts of cross-border and transnational cooperation in Europe. Springer, Cham. pp. 7-23.

ScOTT, J. W. 2014: Bordering, border politics and cross-border cooperation in Europe. Working Paper 7. - In: EUROBORDERSCAPES. Bordering, political landscapes and social arenas: potentials and challenges of evolving border concepts in a post-cold war world. http://www.euborderscapes.eu/fileadmin/user_upload /Working_Papers/EUBORDERSCAPES_Working_Paper_7_Scott.pdf (letöltés: 2016. december 3.).

STEFÁN K.-TRÓCSÁNYI A. 2012: Geographic aspects and spread of the cultural economy in Hungary. - In: TRÓCSÁNYI A.-PIRISI G. (szerk.): The role of the cultural economy and tourism in the renewal of cities. Publikon, Pécs. pp. 89-105. 
SvensSON, S.-NoRdLund, C. 2015: The building blocks of a Euroregion: novel metrics to measure cross-border integration. - Journal of European Integration 37. 3. pp. 371-389.

VAN Houtum, H. 1999: Internationalisation and mental borders. - Tijdschrift voor Economische en Sociale Geografie 90. 3. pp. 329-335.

van Houtum, H. 2000: An overview of European geographical research on borders and border regions. - Journal of Borderlands Studies 15. 1. pp. 57-83.

VAn Houtum, H.-Kramsch, O.-Zierhofer, W. 2005: Prologue. B/ordering space. - In: van Houtum, H.-Kramsch, O.-Zierhofer, W. (szerk.): B/ordering Space. Ashgate, Aldershot- Burlington. pp. 1-13.

VÁTI 2002: A magyarországi Phare CBC programok eredményei 1995-2001. - VÁTI Területfejlesztési Igazgatóság, Budapest. 103 p.

Wassenberg, B.-Reitel, B.-Peyrony, J.-Rubió, J. 2015: Territorial cooperation in Europe. A historical perspective. - European Commission, Brussels. 172 p.

WAVE - WAter-linked heritage Valorization by developing an Ecosystem approach.

https://istergranum.eu/projektek/futo-projektek/wave-vizhez-kapcsolodo-oroksegek-ertekelese-okoszisztema-alapu-modszertan-kidolgozasaval/?preview=true https://www.interregeurope.eu/wave/

ZSILINCSAR W. 2012: Experiencing cultural land townscapes as a means of experienceing cultural diversity. - In: TrócsánYi A.-PIRISI G. (szerk.): The role of the cultural economy and tourism in the renewal of cities. Publikon, Pécs. pp. 127-136. 